In the absence of previous ovulatory dysfunction the prognosis in post-pill amenorrhoea is good, the ovaries remaining responsive to gonadotrophin stimulation, whether of endogenous or exogenous origin (table V). This is in keeping with the essentially normal appearance of the ovaries in this group (table III). Nevertheless, spontaneous resumption of ovulation may be delayed for many months, and when ovulation was induced in our patients gonadotrophin therapy with its attendant risks and costs often proved necessary (table V).

When considering methods of contraception in women who subsequently want to conceive, women of low body weight, who may be underweight or simply petite, should be included among those for whom an oestrogen-progestagen preparation is possibly contraindicated. It remains to be seen whether the introduction of the low-dose oestrogen preparations will reduce the incidence of what is now becoming the commonest recognised cause of secondary amenorrhoea.

We thank Dr W H Inman, principal medical officer, Committee on Safety of Medicines, for the data on body weights of patients reported to the Committee on Safety of Medicines, and Dr Michael Smith, chief medical officer, Family Planning Association, and the staff of the East Leeds Family Planning Clinic for access to similar data on women starting oral contraception.

\section{References}

1 Shearman, R P, Lancet, 1966, 2, 1110.

2 Halbert, D R, and Christian, D C, Obstetrics and Gynecology, 1969, 34, 161.

${ }^{3}$ Macleod, S C, et al, American fournal of Obstetrics and Gynecology, 1970, 106, 359.

4 Shearman, R P, Lancet, 1971, 2, 64.

5 Starup, J, Acta Obstetricia et Gynecologica Scandinavica, 1972, 51, 341.

6 Steele, S J, Mason, B, and Brett, A, British Medical fournal, 1973, 4, 343.

${ }^{7}$ Larsson-Cohn, U, Acta Obstetricia et Gynecologica Scandinavica, 1969, 48, 416.

8 Golditch, I M, Obstetrics and Gynecology, 1972, 39, 903.

${ }^{9}$ Kemsley, W F F, Annals of Eugenics, 1952, 16, 316.

10 Shearman, R P, and Smith, I D, Fournal of Obstetrics and Gynaecology of the British Commonwealth, 1972, 79, 654.

${ }^{11}$ Fries, H, and Nillius, S J, Acta Psychiatrica et Neurologica Scandinavica, 1973, 49, 653

12 Fries, H, and Nillius, S, Acta Psychiatrica et Neurologica, 1973, 49, 669.

${ }^{13}$ Committee on Safety of Drugs, British Medical fournal, 1970, 2, 231.

14 Frisch, R E, and Revelle, R, Science, 1970, 169, 397.

15 Johnston, F E, et al, American fournal of Diseases of Children, 1975, 129, 19.

16 Palmer, R L, et al, British Medical fournal, 1975, 1, 179.

17 Boyar, R M, et al, New England fournal of Medicine, 1974, 291, 861.

\title{
Familial cancer on a Scottish island
}

\section{R D HILL}

British Medical fournal, 1976, 2, 401-402

\section{Summary}

When the causes of death were determined in 18 relations of a child with Fanconi's anaemia 10 deaths were found to be due to carcinoma of various organs. Cases of osteogenic sarcoma, leukaemia, and Marfan's syndrome were also discovered among relatives. The family was from a remote community in the Hebrides and there was considerable intermarriage. Suggestive evidence of heterozygosity was found by chromosome analysis.

\section{Introduction}

Fanconi's anaemia was first described in 1927 in three brothers with pancytopenia and multiple congenital abnormalities. ${ }^{1}$ The condition is inherited as an autosomal recessive of low penetrance, and affected individuals have growth retardation; various congenital abnormalities, of which skeletal defects and faults in skin pigmentation are the most common; a progressive pancytopenia; and frequent chromosome breaks in fibroblast and lymphocyte cultures. It usually begins before the age of 10 and may terminate in acute myelogenous or monomyelocytic leukaemia.

Groups of patients with Fanconi's anaemia have been reported $^{2-5}$ in whom there appeared to be a definite increase in the incidence of leukaemia and other tumours, in both patients and their relatives (see table). The cell type in all reported cases has been acute myelogenous or monomyelocytic leukaemia. ${ }^{4}$ This is in striking contrast to the usual pattern of childhood leukaemia: in one series of 181 patients, ${ }^{6}$ for example, 168 had acute lymphoblastic leukaemia and only 13 acute myelogenous leukaemia.

There is only scant reference to a link with other types of neoplasm. Swift ${ }^{7}$ studied 474 relatives and found that 27 of the 102 deaths were due to neoplasms, as against an expected $17 \cdot 4 \pm 3 \cdot 8$ (SD) in an unselected population-a significant difference at the 0.05 level. There were also four neoplasms in relatives dying from other causes and eight in living relatives.

\section{Case report}

A 5-year-old girl from a Hebridean island (population 1350) was born on 5 May 1969 with bilateral dislocation of the hips and malformations of both thumbs. In January 1975 she was found to be very pale and listless, with haemoglobin $4 \mathrm{~g} / \mathrm{dl}$; white blood count $2.05 \times 10^{9} / 1\left(2050 / \mathrm{mm}^{3}\right)$, with polymorphs $0.44 \times 10^{9} / 1\left(440 / \mathrm{mm}^{3}\right)$; platelets $3 \times 10^{9} / 1\left(3000 / \mathrm{mm}^{3}\right)$; and reticulocytes $4 \%$. Fetal haemoglobin was grossly raised at $32 \%$. The peripheral film showed a normochromic, macrocytic anaemia with neutropenia and thrombocytopenia but no blast cells. Neutrophils in the buffy coat had partially defective granulations and a normoblast was present. The Ham test gave negative results.

Marrow smear showed patchy areas of cellular marrow intermingled with hypoplastic fatty areas. Megakaryocytes were reduced but myeloid and erythroid series were normally represented in the cellular areas. Red cell precursors, however, showed features of dyserythropoiesis-that is, multinuclearity, Howell-Jolly bodies, and late megaloblasts. Foamy reticulum cells were prominent, together with several tissue mast cells, characteristic of aplastic states. There was increased iron in the reticulum cells. There was no evidence of leukaemia.

These findings, coupled with the skeletal abnormalities, were thought to be typical of Fanconi's anaemia.

\section{Family studies}

The patient's parents were second cousins. Eighteen members of previous generations had died, $10(55 \%)$ from some form of neoplasm: 
Incidence of malignant disease in patients with Fanconi's disease and their relatives*

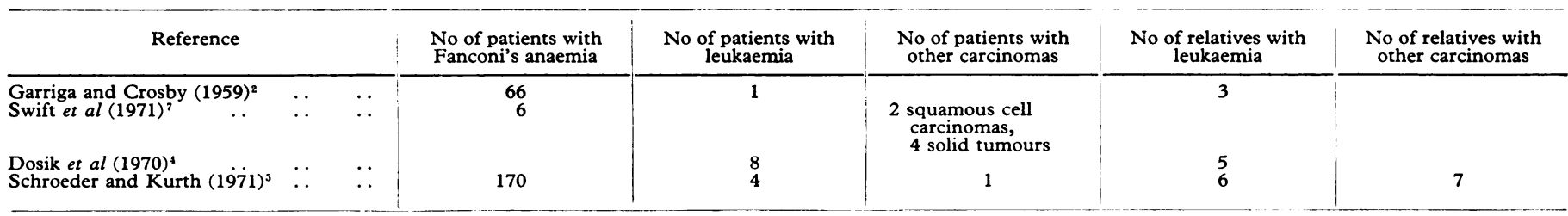

* Numbers of relatives at risk were not stated in these papers.

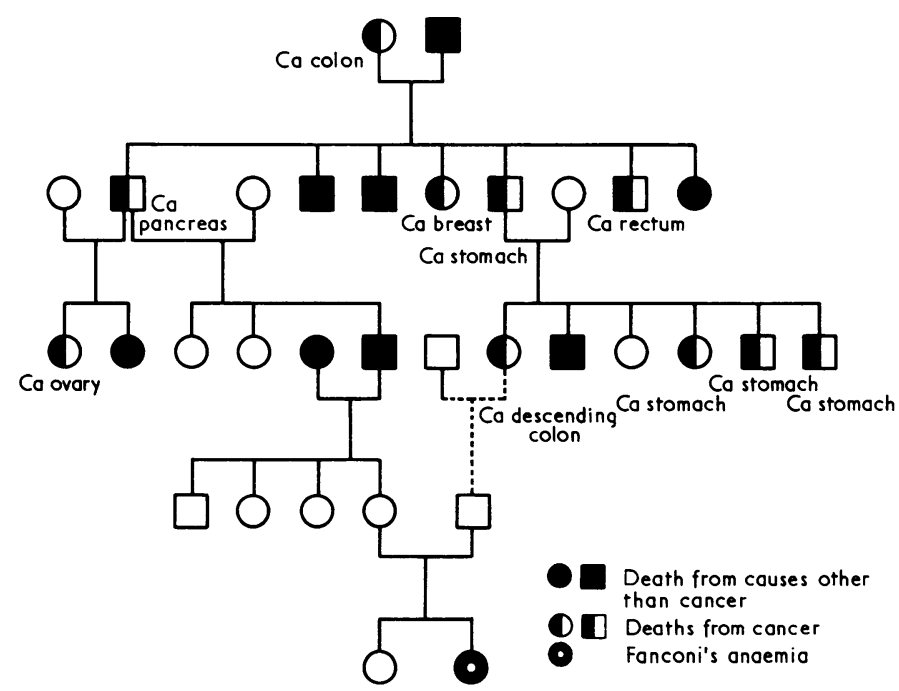

Family tree showing causes of death in ancestors of patient suffering from Fanconi's anaemia.

one from breast cancer, one from cancer of the ovary, and the remainder from neoplasms of the digestive tract (see figure). This compares with figures for cancer mortality of $15.4 \%$ for Scotland and $13.4 \%$ for the island between 1930 and 1973 .

An 11-year-old cousin died from metastases from an osteosarcoma of the right knee in 1968, a 6-year-old cousin died from acute lymphoblastic leukaemia in 1972, and a 3-year-old cousin developed acute lymphoblastic leukaemia in 1974.

When this pedigree was being constructed it became known that there were two patients, one with certain and one with almost certain Marfan's syndrome, who were related, more than once, to the index family. In addition, a child died in a mainland hospital in 1972, microcephalic, mentally retarded, and blind, who belonged to the same pedigree.

\section{Fetal haemoglobin and chromosome studies}

An attempt was made to identify heterozygotes by studying fetal haemoglobin and chromosome patterns in the patient and 17 relatives. Fetal haemoglobin levels (determined by staff of the MRC Human Biochemical Genetics Unit, London) were normal in all the relatives except the living laukaemic child, who had a raised value of $3 \cdot 2 \mathrm{~g} / \mathrm{dl}$.

Chromosome analysis (carried out at the MRC Clinical and Population Cytogenetics Unit, Edinburgh) was performed on peripheral blood leucocytes cultured in vitro. The frequency of cells with chromosome and chromatid aberrations in the patient with Fanconi's anaemia was $30 \%$, and the incidence in both parents was around $10 \%$, compared with an average of around $4 \%$ in normal individuals not exposed to known mutagens. A relatively high incidence of aberrations was found in two of the three half-aunts and a half-uncle, but this may not have been significant since there is wide individual variation in normal people.

\section{Discussion}

While all the cases mentioned could have occurred by chance, they represent an extraordinary concentration of uncommon diseases in one small practice of 1350 patients living in an isolated pair of islands 60 miles from the Scottish mainland. The frequency of cancer among relatives of a patient with Fanconi's anaemia, also reported by Swift, ${ }^{7}$ lends some support to a genetic link, although the two children with leukaemia had lymphoblastic rather than myelogenous cell types.

In experimental animals genetic susceptibility has been shown to determine the frequency and type of neoplasm for both spontaneous tumours and those induced by chemical carcinogens or oncogenic viruses. ${ }^{8}$ Analysis of genetic factors in human beings is more difficult, but familial clusters of neoplasms ("cancer families") are well known. ${ }^{9}$ Specific autosomal dominant syndromes associated with malignant disease are the naevoid-basal cell carcinoma syndrome, polyposis coli, and neurofibromatosis. Autosomal recessive syndromes are much rarer and include Fanconi's anaemia, ataxia telangiectasia, Bloom's syndrome, xeroderma pigmentosum, Werner's syndrome, dyskeratosis congenita, and the Chediak-Higashi syndrome. Their rarity might make them appear relatively unimportant, but if, as seems likely in several cases, heterozygosity predisposes to cancer, finding out how these genes act might be valuable for the study of cancer.

Leukaemia occurs 20 times more often in patients with Down's syndrome than in the general population, ${ }^{10}$ and links between several genetic diseases and leukaemia or lymphoreticular neoplasia ${ }^{11}$ suggest that such neoplasms require genetic susceptibility..$^{2}$

The present data are insufficient to conclude that individuals who are heterozygous for the Fanconi gene have a higher incidence of chromosome aberrations, but they are suggestive, and further studies are needed both to identify gene carriers and to see if there is an increased rate of chromosomal aberrations in relatives who develop cancer.

All the families in the present study have lived for the past few generations in one restricted area of the islands and have tended to marry much more often within the area than outside. ${ }^{13}$ All the children and their parents were born within a few hundred yards of each other. Doctors who work in such isolated communities have an excellent opportunity to examine all cases of physical or mental abnormality for possible congenital or familial influences. Possibly the prevalence of such uncommon diseases as those reported here will be found to have been underestimated.

\section{References}

${ }^{1}$ Fanconi, G, Fahrbuch für Kinderheilkunde, 1927, 117, 257.

2 Garriga, S, and Crosby, W H, Blood, 1959, 14, 1008.

3 Swift, M, Zimmerman, D, and McDonough, E R, fournal of the American Medical Association, 1971, 216, 325.

4 Dosik, H, et al, Blood, 1970, 36, 341.

5 Schroeder, T M, and Kurth, R, Blood, 1971, 37, 96.

${ }^{6}$ Mangalik, A, et al, Blood, 1966, 27, 490.

7 Swift, M, Nature, 1971, 230, 370.

${ }^{8}$ Heston, W E, Cancer Research, 1965, 25, 1320.

9 Lynch, H T, Hereditary Factors in Carcinoma. Berlin, Springer-Verlag, 1967.

10 Wald, N, et al, Lancet, 1961, 1, 1228.

11 Miller, J, New England fournal of Medicine, 1966, 275, 87.

12 Peterson, R D A, et al, in Progress in Medical Genetics, ed A G Steinberg and A G Bearn, vol 4, p 1. London, Heinemann, 1965.

13 Morton, N E, et al, Annals of Human Genetics, 1976, 39, 339. 